\title{
DNA 相補結合を用いたマイクロ光学システムの高集積化に関する研究
}

\author{
Development of Integrated Micro Optical Systems using DNA Self-recognition
}

\begin{abstract}
田代裕之 大阪大学
Hiroyuki Tashiro, Osaka University

林照剛 九州大学

Terutake Hayashi, Kyushu University

\author{
道畑正岐 大阪大学
}

Masaki Michihata, Osaka University

\author{
Yasuhiro Takaya, Osaka University
}

高谷裕浩 大阪大学

Research on micro component self-assembly is required to achieve fabrication of functional MEMS devices aggregated from different components of different materials. Self-assembly is a process in which components spontaneously form ordered aggregates without human intervention. In this paper, we propose DNA self-assembly in which micro components are assembled on designated locations on Si substrate, utilizing DNA base sequence complementation and hybridization for adhesion. Surface coverage of thiol modified single strand DNA on $20 \mu \mathrm{m}$ square Au binding sites on Si substrate are measured, so as to verify the number of single strand DNA involved in the hybridization bonding between component and substrate.
\end{abstract}

\section{Key Words: DNA, Self-recognition, Self-assembly, Micro Optical system}

\section{1. 研究背景}

MEMS とは Si 基板上に機械構造をもつ微細デバイスの総 称である. 特に光学 MEMS はマイクロサイズの光学デバイ スを提供できることから, 光通信ネットワークなどの幅広い 光学分野で応用されており, 光ファイバスイッチングデバイ スや可変減衰器, Fig.1 のようなマイケルソン型分光器など の開発が進められている. 現在これら光学 MEMS 関連市場 の拡大に伴い, その小型化と大量生産が求められる.

光学 MEMS の製造における微細加工はフォトリソグラフ イなどのシリコン IC プロセスが主流だが，この手法は複雑 な手順が多く, 複数種のマイクロ光学素子を 1 つずつ $\mathrm{Si}$ 基 板上に加工していく為, 大量生産には不向きである.しかし， あらかじめ大量に作製した複数種のマイクロ光学素子を $\mathrm{Si}$ 基板上へ集積化する手法についても，シリコン IC プロセス や材料との適合性などの制限を受ける.またマイクロサイズ では表面張力が支配的な力となり部品のハンドリングが非 常に難しく，その集積化が困難である.

そこで複数種のマイクロ光学素子が同時並列なプロセス で, 自動的に Si 基板上の所定位置に組み立てられるセルフ アセンブリ加工が様々な手法により研究されている. 本研究 では一本鎖 DNA が二本鎖 DNA に結合する力を，マイクロ 光学素子と基板間の接着力に用いた DNA セルフアセンブリ を提案する. DNA セルフアセンブリは特定の DNA 塩基どう しのみが結合する DNA 相補性により, 異なるマイクロ光学 素子に異なる DNA 塩基配列を使い分けることで, 複数種の マイクロ光学素子を同時並列に, かつ自動的に Si 基板上の 所定位置に組み立てることが可能である。これにより DNA セルフアセンブリは, マイクロ光学素子の集積プロセスにお ける部品のハンドリングや時間の効率化, およびシリコン IC プロセスとの併用が可能になると考えられる.

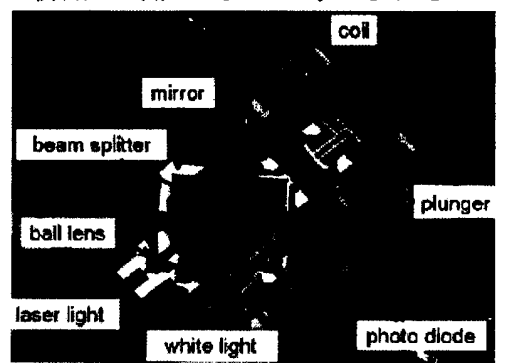

Fig.1 Michelson Spectrometer assembled in millimeter size. ${ }^{[1]}$
2. 研究目的

本研究では, マイクロ光学素子を想定した一辺 $20 \mu \mathrm{m}$ の矩 形部品を, DNA セルフアセンブリによって Si 基板上に組み 立てるマイクロ光学デバイスの効率的な製造プロセスの確 立を目指している. 具体的に, 要求される組み立て技術要素 として以下の 6 つが考えられる。

一辺 $20 \mu \mathrm{m}$ の矩形部品が,

(1)DNA 塩基配列の相補性により選択的に位置決めされる. (2)位置誤差 $\leq 1 \mu \mathrm{m}$ ，かつ角度誤差 $\leq 0.57^{\circ}$ の精度で組み立つ. (3)特定の表裏の向きで組み立てられる.

(4)アセンブリされる確率を向上させ，歩留まりを減らす.

(5)組み立つ上で最適な DNA 塩基長および塩基配列の決定. (6)DNA セルフアセンブリされる反応時間の効率化. 本研究はマイクロ光学デバイスを効率的に DNA セルフアセ ンブリによって組み立てる製造プロセスに要求される(1) (6)の組み立て技術要素を実現する実験方法および実験条件 の検証を目的としている.

3. DNA セルフアセンブリの原理

通常DNAは生体内において二本鎖の状態で存在するが，2 本の一本鎖DNAを繋いでいるのは互いの配列中DNA塩基の 水素結合である. 塩基にはアデニン $(\mathrm{A})$, グアニン $(\mathrm{G})$, シト シン(C), チミン(T)の4種類あり, $\mathrm{A}$ は $\mathrm{T}$ と, $\mathrm{C}$ は $\mathrm{G}$ とのみ塩基 対を形成し，それぞれ9pNと21pNの結合力を生じる. ${ }^{[2] こ の ~}$ 特性をDNA塩基の相補性, また相補的な塩基配列をもつ2本 の一本鎖DNAが二本鎖DNAに結合することをハイブリダイ ゼーションと呼ぶ. 二本鎖DNAは一定温度を上回ると塩基同 士の結合が離れ，二本の一本鎖DNAへと解離する. 特に, 二 本鎖DNAが半分の割合で解離した温度を融解温度 $\mathrm{T}_{\mathrm{m}}$ と呼び, DNAのハイブリダイゼーションは, $\mathrm{T}_{\mathrm{m}}$ より $25^{\circ} \mathrm{C}$ 低い温度 $\mathrm{T}_{\max }$ で反応速度が最大になることが知られている.

DNAセルフアセンブリではFig.2のように, まず部品と基板に それぞれ相補的な一本鎖DNA(DNA1 とDNA1'，DNA2 と DNA2')を修飾する。 そして緩衝溶液中で部品が基板上の相 補的なDNAが修飾された組み立て位置に接近した際, DNA がハイブリダイゼーションすることでDNA1の部品はDNA1' 上に，DNA2の部品はDNA2'上にそれぞれ選択的にSi基板上 の所定の位置へ組み立てられる.また相補的ではない一本鎖 DNAは互いに反発するため, 部品が非相補的な塩基配列をも つ基板上の間違った位置に組み立てられることはない. 本研究で主に用いるDNA相補鎖は, 部品側に修飾する長さ 
約 $8.5 \mathrm{~nm}$ のアデニン25塩基長の一本鎖DNA(A25mer) と，基板 上に修飾するチミン25塩基長の一本鎖DNA(T25mer)であり， $\mathrm{T}_{\mathrm{m}}=61.5^{\circ} \mathrm{C}, \mathrm{T}_{\mathrm{max}}=40^{\circ} \mathrm{C}$ であ. 部品の組み立てプロセスでは, A25merを修飾した部品を含む緩衝溶液を，T25merを修飾し た基板上へ導入した後， $\mathrm{T}_{\max }$ に設定した恒温槽内に一定時間 置いてDNAをハイブリダイゼーションさせる.

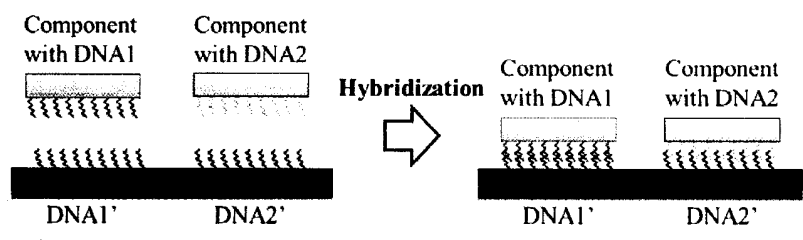

Fig.2 Schematic of DNA self-assembly with two complementary base sequence in buffer solution.

\section{4. 矩形部品と $\mathrm{Si}$ 基板}

実験に用いる矩形部品はFig.3に示す一辺 $20 \mu \mathrm{m} \times 20 \mu \mathrm{m}$, 厚 さ $5 \mu \mathrm{m}$ の $\mathrm{SiO}_{2}$ 層の片面に $\mathrm{Cr} / \mathrm{Au}$ 層(厚さ $10 \mathrm{~nm} / 50 \mathrm{~nm}$ )が蒸着され たものである。A25merは5'末端に修飾されたThiol基により 矩形部品Au面にのみ特異的に共有結合される.
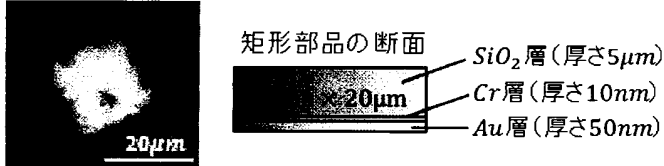

Fig.3 Left: Microscopic image and, Right: schematic cross section of Silicon square components.

またSi基板にはFig.4に示すような $4 \mathrm{~mm} \times 4 \mathrm{~mm} の \mathrm{Si}$ ウェハ上 にLED描画とEB蒸着を用いて, 矩形部品を組み立てる土台と して $\mathrm{Cr} / \mathrm{Au}$ (厚さ $5 \mathrm{~nm} / 50 \mathrm{~nm}$ )のパターニング(Au binding site)が 作製されている．矩形部品の寸法に合わせ，Au binding site の寸法は $20 \mu \mathrm{m} \times 20 \mu \mathrm{m}$ であり, $\mathrm{Si}$ 基板上には縦横20個ずつ計 400個並んでいる．矩形部品之同様，基板上の $\mathrm{Au}$ binding site にも5'末端にThiol基が修飾されたT25mer(以下Thiol-T25mer) を特異的に共有結合させる.

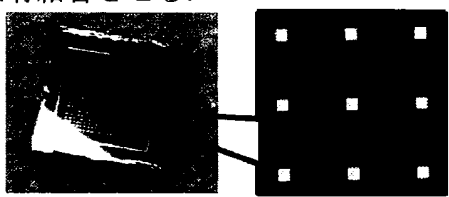

Fig.4 Silicon substrate and its individual Au binding sites.

矩形部品Au面に修飾されたA25merが，基板上Au binding site に修飾されたT25merとハイブリダイゼーションした場合, 矩 形部品はAu binding siteにDNA結合力により組み立てられる

\section{Au binding site 上に修飾される T25mer の DNA 密度測定 5-1 実験目的}

$\mathrm{Si}$ 基板上の Au binding site に Thiol-T25mer を修飾するプロ セスでは Thiol-T25mer が 4pmol/ $\mu \mathrm{L}$ 含まれる DNA 修飾溶液 $1 \mathrm{~mL}$ 中に Si 基板を $60^{\circ} \mathrm{C}$ で 24 時間十室温で 48 時閒浸してい るが, 1 つあたりの Au binding site に修飾される Thiol-T25mer の DNA 密度 $\left[\mathrm{mol} / \mathrm{m}^{2}\right]$ は DNA 修飾溶液の濃度と同じではない そこで矩形部品と $\mathrm{Au}$ binding site 間の DNA 結合に関与する DNA 量を定量化するために DNA 密度を測定する.

5-2 DNA 密度の測定手法

Mirkin $ら^{[3]}$ は蛍光光度計を用いて, 大きさ $10 \mathrm{~mm} \times 6 \mathrm{~mm}$ の $\mathrm{Au}$ 薄膜に Thiol 基で共有結合された Fluorescene 末端修飾 12 塩基長 DNA の密度を測定し, DNA 密度は最密で $1.8 \times 10^{-7}$ $\mathrm{mol} / \mathrm{m}^{2}$ 程度であるとしている. しかし，ここでは $\mathrm{Au}$ の総面 積が小さく, 共有結合される Thiol-T25mer が微量であるため
蛍光光度計の検出分解能を越えている。そこで蛍光標識 DNA(Thiol-T25mer-Alexa fluor 488) が共有結合された 1 つの $\mathrm{Au}$ binding site から発せられる蛍光輝度を蛍光顕微鏡画像か ら ImageJ で取得し, リファレンスとなる既知の DNA 密度に 対する蛍光輝度と比較することで DNA 密度を決定した。リ ファレンスの蛍光輝度は，Fig.5 のようにスライドガラスと 厚さ $65 \mu \mathrm{m}$ の両面テープで張ったカバーガラスの隙間に濃度 既知の蛍光 DNA 溶液を注入し蛍光画像を取得している。 こ こで蛍光 DNA 溶液の濃度は, Mirkin らが測定した $10^{-7} \mathrm{~mol} / \mathrm{m}^{2}$ オーダーで仮に蛍光 DNA が $20 \mu \mathrm{m} \times 20 \mu \mathrm{m}$ の Au binding site に共有結合された場合の $\mathrm{mol}$ 数と, カバーガラスとスライド ガラスの隙間 $20 \mu \mathrm{m} \times 20 \mu \mathrm{m} \times 65 \mu \mathrm{m}$ の体積領域内に同じ $\mathrm{mol}$ 数が含まれるように調整している。

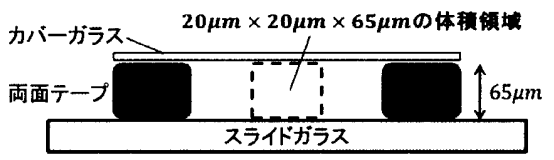

Fig.5 Setup for acquiring reference fluorescent brightness.

\section{5-3 DNA 密度の測定結果}

濃度 $4 \mathrm{pmol} / \mu \mathrm{L}$ の DNA 修飾溶液中で $\mathrm{Si}$ 基板の Au binding site に Thiol-T25mer-Alexa fluor 488 を共有結合させ蛍光輝度

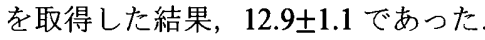

これに対して上記の手法で蛍光輝度のリファレンスを DNA 密度 $1.0 \times 10^{-7} \mathrm{~mol} / \mathrm{m}^{2}, 5.0 \times 10^{-8} \mathrm{~mol} / \mathrm{m}^{2}, 1.0 \times 10^{-8} \mathrm{~mol} / \mathrm{m}^{2}$, $5.0 \times 10^{-9} \mathrm{~mol} / \mathrm{m}^{2}$ の 4 点について取得した結果を Fig.6に示す.

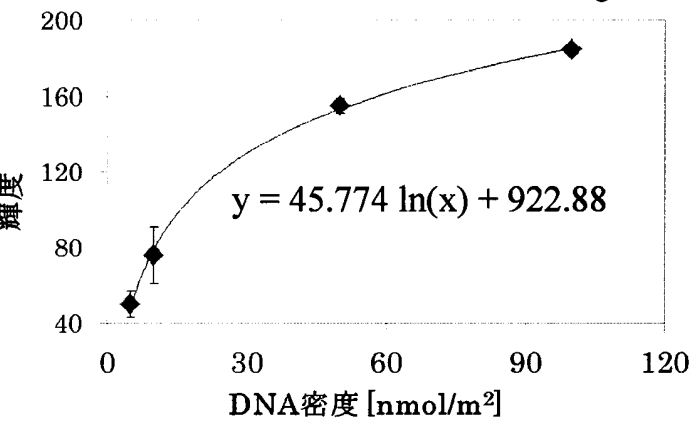

Fig.6 Reference data of DNA coverage - Fluorescent brightness.

4 点の対数近似式に Au binding site $の$ 蛍光輝度 12.9 を代入 し, 導かれた Au binding site 上の DNA 密度は $2.3 \times 10^{-9} \mathrm{~mol} / \mathrm{m}^{2}$, すなわち 1 つの Au binding site あたりに $5.6 \times 10^{5}$ 本の Thiol-T25mer が共有結合している計算である.

5-4 考察

全ての T25mer が結合に関与したとして A-T 塩基対が $9 \mathrm{pN}$ の結合力であることを用いると，矩形部品－基板間には $\leq 126 \mu \mathrm{N}$ の結合力が生じると考えられる。これはマイクロの サイズで支配的な表面張力と同程度のオーダーの力である.

\section{6. 結論}

蛍光標識 DNA を用いることでThiol-T25merの DNA 密度, および矩形部品と Au binding site の結合に介する T25mer の 本数を導き, それらが表面張力と同程度の結合力を発揮する ことを示した。

\section{【参考文献】}

[1] R. F. Wolffenbuttel Journal of Micromechanics and Microengneering 15 (2005)

[2] Hermann E. Gaub, Sequence-dependent mechanics of single DNA molecules

[3] Chand A. Mirkin et.al. Analytical Chemistry, Vol. 72, No. 22 , Nov. 2000 